Ilmu Dakwah: Academic Journal for Homiletic Studies Vol 10 No 2 Juli-Desember 2016 p-ISSN 1693-0843 http://journal.uinsgd.ac.id/index.php/idajhs DOI: http://dx.doi.org/10.15575/jid.v10i1.334

\title{
Dakwah Kultural dalam Upacara Adat Ngalaksa
}

\author{
Mukhlis Aliyudin* \\ UIN Sunan Gunung Djati Bandung \\ *mukhlisaliyudin@yahoo.com
}

\begin{abstract}
Religion and culture continue to color the human life. In fact, the two are inseparable, complementary to each other and give meaning. Religion is always alive and embedded in cultural values, otherwise the culture is always cooperative with religious values. Not a bit of cultural values to accommodate religious values. And in between the spread of religious and cultural value to the community is by propaganda. As happened in the community Rancakalong Sumedang ceremony Indigenous Ngalaksa, which indirectly has happened blend of religious values with the local cultural values, and propaganda with the culture in this area is considered appropriate because it has made this region a peaceful, secure, peaceful, and mutual respect among fellow citizens.
\end{abstract}

Keyword : Dakwah, Culture, Traditional ceremonies

\section{ABSTRAK}

Agama dan budaya senantiasa mewarnai kehidupan manusia. Babkan keduanya tidak bisa dipisabkan, satu sama lainnya saling mengisi dan memberi makna. Agama senantiasa hidup dan melekat dalam nilai-nilai budaya, sebaliknya budaya senantiasa kooperatif dengan nilai-nilai agama. Tidak sedikit nilai-nilai budaya mengakomodir nilai-nilai agama. Dan di antara penyebaran nilai agama dan nilai budaya ke tengah masyarakat adalah dengan dakwah. Seperti yang terjadi di masyarakat Rancakalong Sumedang dengan upacara Adat Ngalaksa, yang secara tidak langsung telah terjadi perpaduan antara nilai agama dengan nilai budaya lokal, dan dakwah dengan berbudaya di daerah ini dinilai tepat karena telah menjadikan daerah ini tentram, aman, damai, dan saling menghargai di antara sesama masyarakatnya.

Kata Kunci : Dakwah, Budaya, Upacara Adat

Naskah diterima: 6 Sept 2016, direview 1 Nov 2016, disetujui: 14 Nov 2016

\section{PENDAHULUAN}

Dalam hidup dan kehidupan manusia, agama berfungsi sebagai suatu sistem nilai yang memuat norma-norma tertentu. Secara umum, norma-norma tersebut menjadi kerangka acuan dalam bersikap dan bertingkah laku agar sejalan dengan keyakinan agama yang dianutnya (Ishomuddin, 2002: 35). Itulah yang disebut sebagai perilaku keagamaan, 
yang seringkali menjadi bagian dari kebudayaan manusia yang terdapat dalam berbagai sosio-kultur yang berbeda-beda. Atas dasar itu, agama sering dipandang memiliki fungsi sublimatif, dalam arti bahwa agama memiliki peran tertentu dalam setiap aspek kehidupan. Dan di antara fungsi sublimatif ini, diwakili dengan perannya sebagai integrator dan mobilisator (penggerak) perubahan sosial.

Kaitannya dengan kebudayaan, menurut Ralph Linton kondisi ini disebut design for living yaitu garis-garis atau petunjuk dalam hidup. Artinya bahwa kebudayaan adalah suatu garis-garis pokok tentang perilaku atau blueprint for behavior, yang menetapkan peraturan mengenai apa yang harus dilakukan, apa yang dilarang dan lain sebagainya.

Adapun unsur-unsur budaya yang menjadi petunjuk hidup antara lain: (1) unsur-unsur yang menyangkut penilaian (valuational elements), misalnya apa yang baik dan buruk, apa yang menyenangkan dan tidak menyenangkan, apa yang sesuai dengan keinginan dan apa yang tidak sesuai dengan keinginan; (2) unsur-unsur yang berhubungan dengan apa yang seharusnya (prescriptive elements) seperti bagaimana orang harus berlaku; dan (3) unsur-unsur yang menyangkut kepercayaan (cognitive elements), seperti harus mengadakan upacara pada event-event tertentu (dalam Soekanto, 2015: 198).

Terlebih kalau berpegang pada pendapat Mac Iver yang menyatakan bahwa kebudayaan adalah ekspresi jiwa yang terwujud dalam cara-cara hidup dan berpikir, pergaulan hidup, seni kesusastraan, agama, rekreasi dan hiburan. Atau didasarkan pada pendapat Kingsley Davis, yang menyatakan bahwa kebudayaan mencakup segenap cara berpikir dan bertingkah laku, yang timbul karena interaksi yang bersifat komunikatif (dalam Soekanto, 2015: 341-343), maka kebudayaan secara fungsional berfungsi untuk dijadikan acuan dalam cara berpikir, gaya hidup, dalam pergaulan atau pola berhubungan hubungan satu sama lain. Kemudian Soerjono Soekanto memperjelas, bahwa:

Kebudayaan mengatur agar manusia dapat mengerti bagimana seharusnya bertindak, berbuat, menentukan sikapnya kalau mereka berhubungan dengan orang lain. Karena kebudayaan mewujudkan norma dan nilai sosial kemasyarakatan. Kebudayaan, akan mewujudkan kaidah-kaidah yang dinamakan peraturan yang bertujuan membawa suatu keserasian dan memperhatikan hal-hal yang bersangkut paut dengan keadaan lahiriah dan bathiniah manusia, yang salah satunya mengatur pola perilaku (patterns of behavior), dimana pola-pola perilaku tersebut

100 Ilmu Dakwah: Academic Journal for Homiletic Studies, Vol. 10 No.2 | Juli-Des 2016 
merupakan cara-cara masyarakat bertindak atau berkelakuan yang sama dan harus diikuti oleh semua anggota masyarakat. Pola perilaku tersebut dilakukan dan dilaksanakan pada khususnya apabila seseorang berhubungan dengan orang lain yang dinamakan social organization (2015:195).

Berdasarkan penjelasan di atas, dapat dipahami bahwa agama dan budaya merupakan bagian inheren dari kehidupan masyarakat, karena ia memiliki fungsi mendasar dalam kehidupan masyarakat, maka agama dan sosial-budaya juga mempengaruhi seluruh aspek kehidupan masyarakat. Dalam hal ini, Weber beranggapan bahwa jika orang memeluk agamanya secara serius, maka paling tidak tingkah-lakunya akan dipengaruhi oleh agamanya (Cuzzort dan King, 1987: 11).

Namun agama tidak serta merta diterima dan mempengaruhi seseorang kalau tidak diperkenalkan dan diajarkan. Perlu ada upaya penyebaran ajaran agama, dan di antara upaya penyebarannya dengan dakwah, tepatnya dakwah kultural. Dakwah kultural merupakan dakwah yang berbasiskan pada agama, atau dakwah yang dalam diseminasi informasi ajaran agama, yang disisipkan dalam budaya atau nilai-nilai budaya setempat. Sehingga mudah diterima dan diamalkan oleh para madunya.

Di antara daerah yang dinilai merepresentasikan dakwah kultural, yaitu penyebaran agama dalam budaya sehingga benar-benar inheren dalam kehidupan masyarakat adalah di daerah Rancakalong Kabupaten Sumedang. Sumedang sebagai bagian dari daerah Tatar Sunda, memiliki sejumlah keunikan dalam mengapresiasi tradisi kebudayaan.

Dibandingkan dengan wilayah-wilayah lain yang secara umum dalam aspek keagamaan sangat dominan mentalitas santrinya, Sumedang masih menunjukkan gejala-gejala priyayi, bahkan sedikit abangan untuk kasus-kasus tertentu (Geertz, 1989). Bahkan pengaruh Mataram Islam telah menempatkan pada posisi yang khusus di mana pola berbahaa halus dan bertingkat bisa diterangkan secara historis di wilayah ini, mana yang asli Sunda dan bukan. Apakah sistem kekerabatan kaum bangsawan menak atau para pewaris tahta kerajaan Sumedang Larang, yang berafiliasi pada kaum bangsawan Solo dan Yogyakarta oleh sebab-sebab akar historis mereka yang cukup kompleks (Koentjaraningrat, 1995: 305), termasuk juga faktor aktualisasi nilai-nilai agama terhadap aktivitas sehari-hari termasuk budaya di dalamnya, secara umum di kalangan menak Sumedang.

Ilmu Dakwah: Academic Journal for Homiletic Studies, Vol. 10 No.2 | Juli-Des 2016101 
Fenomena di atas menggambarkan adanya bukti pemikiran dan tingkat religi yang terdapat pada masyarakat Sumedang, khususnya Rancakalong, sebagai cerminan pola dakwah kultural berdasarkan warna warni yang kaya dan unik yang diperkaya oleh kearifan lokal, sehingga menampilkan wajah dakwah kultural yang diperkaya oleh nilai-nilai budaya. Sebagaimana dikatakan Asep Saeful Muhtadi (dalam Tajiri, 2007) bahwa masyarakat semestinya disuguhi berbagai kegiatan dakwah yang mampu menyalurkan aspirasi budayanya dan memuaskan selera kulturalnya.

Agama, manusia, dan budaya berhubungan secara dialektik. Hubungan agama, manusia, dan budaya di satu sisi menciptakan sejumlah nilai bagi masyarakatnya, dan pada sisi lain secara bersamaan, manusia secara kodrati senantiasa berhadapan dan berada dalam masyarakatnya (bomosocius) (Kahmad, 2011 : 72). Agama dalam konteks budaya, berada dalam dialektika ini. Oleh karena itu, semua masyarakat yang dikenal di dunia ini, sampai batas tertentu, bersifat religious (Schraf, 1995: 29). Sementara perbedaan agama sebagai produk budaya dengan produk lainnya.

Agama berasal dari proses objektivikasi tertentu yang bernilai transenden. Sebagai proses objektivikasi, maka di dalamnya akan melibatkan hubungan antara kebudayaan dan artefak. Hal yang sama terjadi ketika ada suatu agama masuk pada masyarakat lain di luar masyarakat pembentuknya. Agama itu akan mengalami proses penyesuaian dengan kebudayaan yang telah ada. Ada kompromi nilai atau simbol antar agama yang masuk dengan kebudayaan lokal, yang menghasilkan bentuk baru yang berbeda dengan agama atau budaya asal (Schraf, 1995: 75).

Sementara dakwak dan budaya tidak dapat disangkal lagi keterkaitannya. Keduanya saling mengisi dan membantu dalam membutuhkan dalam menjalankan tugas dan fungsinya. Seperti yang dikatakan Asep Saeful Muhtadi Setiap peristiwa dakwah senantiasa berada dalam konteks budaya yang mengitarinya. Bagaimana subjek dakwah melakukan kegiatan dakwahnya, dan bagaimana mad'u berperilaku di tengah dakwah, tentu saja selalu membawa dan melibatkan latar budayanya (dalam Tajiri, 2015: 93).

Penelitian ini menggunakan metode etnografi. Marvasti (2004:3536) menekankan tiga dimensi etnografi, yaitu keterlibatan dan berpartisipasi dalam topik penelitian, perhatian pada konteks sosial dalam

102 Ilmu Dakwah: Academic Journal for Homiletic Studies, Vol. 10 No.2 | Juli-Des 2016 
Dakwah Kultural dalam Upacara Adat Ngalaksa

pengumpulan data, dan sensitivitas pada bagaimana subjek direpresentasikan dalam teks-teks penelitian.

\section{HASIL DAN PEMBAHASAN}

Berdasarkan data di lapangan diketahui, bahwa Adat Ngalaksa sekalipun bagian dari adat yang hidup dan berkembang di tengah masyarakat Rancakalong, diyakini dan dipahami oleh para pelakunya merupakan bagian dari pelaksanaan syari'at.

Pandangan ini, selain karena secara substantif merupakan ekspresi dari rasa syukur atas karunia yang telah diberikan oleh Allah SW'T, juga sebagai adat telah dikembangkan sejak lama oleh para karubun (leluhur) masyarakat adat Rancakalong yang beragama Islam, serta merupakan adat istiadat sebagai penganut ajaran Islam yang tinggal di wilayah Rancakalong.

Tentunya, tidak mudah untuk mengatakan bahwa Adat Ngalaksa yang hidup dan berkembang di tengah masyarakat adat Rancakalong sebagai bagian dari kegiatan ibadah (dalam perspektif Islam), karena secara terminologis Adat Ngalaksa tidak terdapat dalam syari'at Islam. Tetapi cukup sulit untuk dikatakan bahwa Adat Ngalaksa dipandang sebagai kegiatan yang bertentangan dengan syariat. Karena secara substantif, karakter agama yang omnipresent, yakni bahwa agama baik melalui simbol-simbol atau nilai-nilai yang dikandungnya "selalu hadir di mana-mana", dan ikut serta mempengaruhi bahkan membentuk struktur sosial, dan budaya, ekonomi serta politik yang hidup dan berkembang di tengah masyarakat pemeluknya.

Lebih dari itu semua, nilai-nilai agama memberi dan menjadi panduan nilai bagi seluruh diskursus kegiatan manusia baik yang bersifat sosial-budaya, ekonomi maupun politik. Terlebih, secara sosiologis unsur-unsur kebudayaan dan keyakinan (agama) pada dasarnya tidak berdiri sendiri, tetapi berkaitan di antara dimensi keduanya, karena nilainilai religius (ajaran agama) dalam realitasnya tidak mungkin berdiri sendiri dan berkembang pada ruang hampa (empty space), tetapi senantiasa diolah dan bersinggungan dengan berbagai dimensi lain dalam kebudayaan pada masyarakat pemeluknya.

Pada akhirnya persinggungan antara agama dan kebudayaan sering memunculkan berbagai bentuk pengamalan agama yang berdimensi budaya setelah mengalami proses akulturasi yang cukup panjang. Karenanya, secara sederhana dapat dikatakan, bahwa pada

Ilmu Dakwah: Academic Journal for Homiletic Studies, Vol. 10 No.2 | Juli-Des 2016103 
waktu yang bersamaan, agama dapat dipandang sebagai something in here (sesuatu yang ada di sini) dan bukan something out there (sesuatu yang ada di luar sana).

Berdasarkan uraian di atas, menjadi sangat sulit untuk mengatakan bahwa Adat Ngalaksa merupakan adat yang bertentang dengan syari'at Islam yang menjadi sistem keyakinan masyarakat Rancakalong. Tetapi juga tidak mudah untuk mengatakan bahwa Adat Ngalaksa sebagai bagian dari ibadah (perspektif syari'at Islam) masyarakat setempat. Karena berdasarkan data di lapangan, diketahui bahwa nilainilai yang disampaikan pada Adat Ngalaksa telah tumbuh subur di tengah kehidupan sehari-hari masyarakat adat Rancakalong yang tampak hidup rukun, tentram, damai, saling menghargai, sederhana, dan adanya keseimbangan antara pengamalan ajaran agama dan nilai-nilai budaya setempat.

Data lain menunjukkan adanya kesalingmengisian antara ajaran agama yang dianutnya, yaitu agama Islam dengan adat istiadat yang diwarisi secara turun-temuran dari para karubun (leluhur) mereka. Karena dalam pandangan mereka agama dan budaya tidak mesti dipertentangkan, bahkan bisa saling menguatkan, karena wilayah agama dan wilayah budaya memiliki dan mendapat tempat masing-masing.

Pandangan tersebut di atas, nampaknya merupakan bagian dari semangat yang telah mereka warisi dari penyebar Islam masa awal dalam menyikapi tradisi lokal, yang kemudian dipadukan menjadi bagian dari tradisi "islami", karena berpegang pada suatu kaidah ushuliyyah yang dikenal di lingkungan para pendakwah, khususnya di lingkungan atau kelompok nahdiyyin: Menjaga nilai-nilai lama yang baik, dan mengambil nilainilai baru yang lebih baik.

Adat Ngalaksa pada masyarakat adat Rancakalong, jika dilihat dari awal mula terbentuknya dapat dikatakan sebagai bagian dari kreativitas masyarakat Rancakalong dalam menghadapi persoalan dan dinamika kehidupan pada saat itu, yang telah mendapatkan bencana kekurangan bahan pangan, hingga tidak ada benih padi untuk melakukan kegiatan pertanian. Karenanya Adat Ngalaksa tidak dapat dipisahkan dari situasi dan kondisi serta latar yang menjadi penyebabnya, yaitu kegiatan pertanian pokok (cocok tanam atau padi) yang menjadi tumpuan masyarakat Rancakalong.

Kegiatan dan Adat Ngalaksa tidak dapat dilepaskan dari ide, aktivitas, dan konteks sistem sosial yang terjadi pada awal pembentukkanya. Karena masyarakat Rancakalong sebagaimana

104 IImu Dakwah: Academic Journal for Homiletic Studies, Vol. 10 No.2 | Juli-Des 2016 
masyarakat pada umumnya, memiliki potensi budaya dan kreativitas dalam menjalankan tugasnya yang diberikan oleh Tuhan untuk mengelola bumi, yaitu sebagai khalifah dan sekaligus sebagai abd dihadapan Allah SWT.

Kebudayaan atau adat (Ngalaksa) yang tumbuh di tengah masyarakat Rancakalong, merupakan kreativitas Islami, Imani, dan Ihsani yang diharapkan dapat memberikan kesejahteraan dan kebahagiaan bagi mereka, karena adat tersebut dilandasi oleh semangat rasa syukur atas karunia Allah SWT dalam bentuk keberhasilan pertanian atau panen padi yang mereka dapatkan. Dalam perspektif Islam, perilaku syukur ini merupakan bagian dari ajuran syari'at sebagaimana disampaikan dalam QS. Ibrahim (14):7, Dan (ingatlah juga), tatkeala Tubanmu memaklumkan; "Sesunggubnya jika kamu bersyukur, pasti Kami akan menambah (nikmat) kepadamu, dan jika kamu mengingkari (nikmat-Ku), Maka Sesunggubnya azabKu sangat pedih.

Survivalitas Adat Ngalaksa di tengah kehidupan masyarakat Rancakalong, sampai dengan saat ini, bisa jadi karena telah diyakini dan dirasakan manfaatnya oleh masyarakat setempat. Berbagai tradisi dan adat istiadat yang telah hidup dan berkembang di tengah masyarakat Rancakalong yang menjadi sasaran dakwah, tidak merasa terusik dengan kehadiran Islam yang pada waktu itu masih menjadi nilai-nilai baru, bahkan dikategorikan sebagai "pendatang". Selain itu, terlepas apakah Adat Ngalaksa dipandang sebagai sebuah adat yang tidak menjadi bagian dari tradisi Islam, akan tetapi sebagai sebuah realitas yang hidup dan berkembang di tengah masyarakat adat Rancakalong, Adat Ngalaksa merupakan adat yang sampai sekarang masih tetap dilakukan. Bahkan dipandang oleh para pelakunya sebagai bagian dari nilai-nilai religius yang dipraktikkan oleh para pelakunya, sekalipun di sisi lain dalam praktiknya, aspek-aspek budaya lebih dominan daripada aspek keagamaan. Karena masyarakat pelakunya sendiri mangakui dan memandang sebagai budaya dan bukan praktik keagamaan, tetapi jika dikaji dari latar belakang keberadaannya, bahwa praktik Adat Ngalaksa merupakan bagian dari cara dakwah yang dikembangkan untuk menyebarkan dan menanamkan nilai-nilai keagamaan pada masyarakat setempat, yang pada awalnya sebagai masyarakat yang kental dengan nilai-nilai animisme dan nilai-nilai ajaran Hindu yang dikembangkan oleh kerajaan Galuh Pakuan yang kemudian menjadi Kerajaan Sunda, dan pada akhirnya menjadi Kerajaan Tembong Agung yang menjadi cikal bakal Kerajaan Sumedanglarang (Lubis, 2008: 104).

Ilmu Dakwah: Academic Journal for Homiletic Studies, Vol. 10 No.2 | Juli-Des 2016105 
Dengan demikian, dapat dipahami jika dalam Adat Ngalaksa masih terdapat mitos sebagai sarana yang menghubungkan manusia dengan "keramat", dan dalam perspektif antropologi dapat digolongkan pada rites of intensification, yaitu ritus yang diadakan pada waktu kelompok tertentu mengalami atau menghadapi krisis dan sesuatu yang penting. Sehingga pada tradisi yang tumbuh sebelum masuknya Islam atau "pada awal masuknya Islam" masih di dalam pengaruh tradisi tersebut sampai dengan masuknya ajaran agama Islam (Lubis, 2008: 95).

Terlepas dari adanya pengaruh tradisi yang diturunkan oleh para karubun (leluhur) dan pengaruh ajaran Islam, pada masyarakat adat Rancakalong yang secara keseluruhannya merupakan masyarakat penganut ajaran Islam, dan tidak berarti kepercayaan atau keyakinan lamanya telah hilang dengan sendirinya, sebab dalam kehidupannya masyarakat adat Rancakalong, baik secara pribadi (perorangan) atau dalam bentuk komunitas, keyakinan agama yang mereka anut tidak terlepas dari keyakinan lokal yang berfungsi dalam berbagai tatanan kehidupan sosial budaya.

Dalam realitasnya, masyarakat adat Rancakalong memiliki kebanggaan dan keinginan untuk tetap melanjutkan warisan nenek moyangnya. Sehingga tidaklah heran apabila tradisi yang ada di Rancakalong masih dapat dipertahankan sampai saat ini. Meskipun zaman sudah berbeda, banyak budaya dan tradisi baru datang silih berganti, tetapi masyarakat Rancakalong tetap setia mengamalkan nilainilai tradisi yang salah satunya adalah Adat Ngalaksa.

Dalam praktik kehidupan sehari-hari sebagai bentuk pengalaman Adat Ngalaksa di masyarakat Rancakalong adalah adanya pengembangan pemakaian Adat Ngalaksa ini tidak hanya untuk acara syukuran atas panen padi, tetapi adanya fungsi pelaksanaan Adat Ngalaksa untuk tujuan tertentu, terutama jentreng tarawangsa, yaitu untuk keselamatan rumah baru, hajatan baik yang menikahkan ataupun untuk khitanan.

Pada masyarakat Rancakalong terdapat tradisi acara salametan untuk rumah yang baru dibangun, upacara ini sebagai bentuk syukuran dan doa, agar rumah yang akan ditempati itu menjadi rumah yang bisa menyejukkan, adanya keberkahan, kebahagiaan, keselamatan, dan orang yang menempatinya pun menjadi betah, menjadi bertambah semangat dalam bekerja atau melakukan berbagai aktivitas dalam memajukan keluarga, dan lain sebagainya.

106 Ilmu Dakwah: Academic Journal for Homiletic Studies, Vol. 10 No.2 | Juli-Des 2016 
Nilai-nilai dalam tradisi Ngalaksa, pada sisi tertentu menjadi bagian dari nilai-nilai yang dikembang dan dipertahankan oleh masyarakat adat Rancakalong, pesan nilai untuk hidup rukun dengan sesama yang dilambangkan dengan simbol "Pare" (dimaknai dari kata atau kecap "parerendeng"), yaitu sebuah pesan nilai untuk hidup rukun (sauyunan) dengan sesama. Nilai untuk tidak melakukan perbuatan menggunjing (gibah) yang dilambangkan dengan "kupat leupeut tantangan angin, anu hartina urang ulah sok ngupat jeung ngeupeul", dan "kopi pait" yang mengandung arti "kop pikiran anu pait dina diri urang", "kopi amis" kop pikiran anu amis dina diri urang, artinya agar hidup tidak pelit tapi mesti "berehan" yang berarti mau berbagi. Oleh karena itu bagi masyarakat Rancakalong mesti terbuka ketika ada persoalan, pesan ini dilambangkan oleh simbol "bakakak anu hartina narima, terbuka, tur jujur", agar hidup mendapatkan sesuatu yang terbaik yang dilambangkan dengan "lauk emas anu hartina ari bidup teh kudu sukses menang hasil anu alus," serta nilai-nilai lainnya, merupakan nilai-nilai yang tetap dipertahankan oleh masyarakat adat Rancakalong agar seluruh warga masyarakat Rancakalong mendapatkan kehidupan adil makmur kerta raharja.

Sekalipun banyak warga pendatang di antara warga masyarakat Rancakalong, tetapi kerukunan dan keharmonisan hidup di tengah kehidupan masyarakat tetap terjaga. Mereka merasa bahwa hidup harus rukun, sebagaimana pepatah dan pesan para karubun-nya dalam Adat Ngalaksa. Adat ngalaksa secara tidak langsung berdampak pada hidup dan aktivitas masyarakat Rancakalong yang saling menghargai, menghormati, dan gotong royong ketika satu warga yang membutuhkan bantuan atau pertolongan apa pun.

Kalau diukur dari pesan nilai yang terdapat pada Adat Ngalaksa, terdapat ikatan kekeluargaan di antara masyarakat adat Rancakalong masih begitu kuat, dan sikap penghargaan masyarakat terhadap anggota masyarakat lainnya yang lebih tua, terlebih kepada saebu atau rurukan pada setiap wilayahnya masing-masing, bahkan terhadap saebu atau rurukan lain. Semua itu menunjukkan adanya dampak pesan moral atau nilai-nilai yang disampaikan dan dikembangkan dalam Adat Ngalaksa yang tidak hanya dipandang sebatas pagelaran budaya belaka, tetapi menampilkan nilai-nilai dan pesan-pesan moral kepada seluruh warga masyarakat Rancakalong.

Proses terjadinya akulturasi timbal balik dengan beberapa aspek lokal yang sekiranya tidak bertentangan secara diametris dengan ajaran substantif ajaran Islam, terjadi pada masyarakat Rancakalong yang telah

Ilmu Dakwah: Academic Journal for Homiletic Studies, Vol. 10 No.2 | Juli-Des 2016107 
memiliki budaya. Sehingga secara sosiologis keyakinan (agama) yang dibawa oleh para pemuka agama berasimilasi dengan unsur-unsur kebudayaan setempat, sehingga nilai-nilai ajaran agama yang hidup dan berkembang pada masyarakat Rancakalong tidak berdiri sendiri, tetapi berkaitan di antara dimensi keduanya, karena nilai-nilai religius (ajaran agama) dalam realitasnya tidak berkembang pada ruang hampa (empty space), tetapi senantiasa diolah dan bersinggungan dengan berbagai dimensi lain dalam kebudayaan pada masyarakat pemeluknya. Pada akhirnya persinggungan antara agama dan kebudayaan sering memunculkan dalam berbagai bentuk pengamalan agama yang berdimensi budaya setelah mengalami proses akulturasi yang cukup panjang sesuai dengan konteks yang terjadi di lingkungan sekitarnya.

Adat Ngalaksa secara sosiologis, dapat dipandang sebagai instrumen dalam memahami dunia, dan merupakan bagian dari pandangan dunia (world view) masyarakat setempat yang dipengaruhi oleh keyakinannya, oleh sebab ajaran agama merupakan sesuatu yang ada di sini (something in here). Sehingga secara langsung atau tidak langsung, keyakinan agama dan pemahaman nilai-nilai budaya yang hidup dan berkembang pada masyarakat adat Rancakalong, telah dan akan terus mempengaruhi bahkan membentuk struktur sosial dan budaya warga masyarakat yang menjadi pelakunya.

Fungsi sublimatif nilai-nilai Adat Ngalaksa, setidaknya dapat dilihat dari kehidupan sehari-hari masyarakat adat Rancakalong, ditunjukkan pada aktivitas sehari-hari yang memperlihatkan kondisi hidup yang rukun, subur dan semaraknya aktivitas dan keikutsertaan dalam kegiatan keagamaan, termasuk motivasi dalam membangun sarana fisik tempat ibadah, seperti masjid, surau, dan tempat mengaji anak-anak terus memperlihatkan peningkatan yang signifikan.

Indikasi lainnya adalah bahwa seluruh masyarakat Rancakalong beragama Islam. Karenanya budaya memakmurkan masjid menjadi pemandangan sehari-hari, baik dengan pengajian ibu-ibu, bapak-bapak dan pengajian anak-anak. Fenomena ini dapat dikatakan sebagai bagian dari dampak keyakinan mereka atas amanat karubun (leluhur) mereka. Dengan demikian, sekalipun Adat Ngalaksa tidak berbicara masalah akhirat akan tetapi pesan yang disampaikan pada Adat Ngalaksa terutama pesan moral dan spiritual yang disampaikan melalui simbol-simbol dan irama lagu pada jentreng tarawangsa yang mengamanatkan agar masyarakat Rancakalong menjadi "sajating manusa" dan tidak sebatas menjadi "jelema".

108 Ilmu Dakwah: Academic Journal for Homiletic Studies, Vol. 10 No.2 | Juli-Des 2016 
Pada sisi lain, secara sosial nilai-nilai yang disampaikan pada Adat Ngalaksa menjadi integrator di antara masyarakat yang berbeda kampung (rurukan), karena di antara mereka diikat oleh kesamaan keyakinan dan kesamaan adat istiadat, sehingga Adat Ngalaksa yang dipandang oleh sebagian masyarakat Rancakalong sebagai bagian dari proses implementasi nilai-nilai agama, pada gilirannya merupakan bagian yang tidak terpisahkan dari sistem keyakinan atau agama yang hidup dan berkembang di tengah masyarakat Rancakalong, dan berpengaruh pada tatapikir dan tatalaku warga masyarakat Rancakalong. Keadaan ini, sebagaimana telah dijelaskan oleh Elizabeth K. Nottingham, yang menjelaskan setidaknya terdapat dua fungsi kehadiran sebuah ajaran agama, yaitu fungsi sebagai pendorong terciptanya persetujuan mengenai sifat dan isi kewajiban-kewajiban sosial, serta memainkan peranan vital dalam memberikan kekuatan memaksa yang mendukung dan memperkuat adat-istiadat (Nottingham, 2002: 29).

Fungsi budaya sebagaimana dijelaskan di atas, dipergunakan ketika mereka berhadapan, dan ketika berbeturan dengan realitas kehidupannya. Perubahan yang dilakukan oleh setiap manusia bisa ke arah perubahan (transendensi), atau ke arah bertahan (immanensi), karena manusia senantiasa berhadapan dengan ruang dan waktu yang senantiasa berubah. Kekuatan tarik-menarik itulah yang menyebabkan terjadinya kreativitas dari setiap manusia yang memiliki "otoritas" dalam melakukan kreativitasnya. Kondisi itulah juga diharapkan oleh Al-Quran, yaitu agar manusia mampu melakukan perubahan, sebagaimana disampaikan (QS. Ar Ra'd [13]: 11).

Dengan demikian, dapat dikatakan bahwa awal mula terbentuknya Adat Ngalaksa, merupakan bagian dari kreativitas masyarakat Rancakalong dalam menghadapi persoalan, yaitu suatu keadaan yang memprihatinkan karena terjadi kekurangan bahan pangan, bahkan tidak memiliki benih padi untuk melakukan kegiatan pertanian. Padahal kegiatan pertanian merupakan pekerjaan pokok yang menjadi tumpuan hidup masyarakat Rancakalong.

Dengan demikian, kegiatan dan Adat Ngalaksa tidak dapat dilepaskan dari ide, aktivitas, dan konteks sistem sosial yang terjadi pada awal pembentukannya. Karena masyarakat Rancakalong sebagaimana masyarakat manusia pada umumnya, memiliki potensi budaya dan kreativitas dalam menjalankan tugasnya yang diberikan oleh Tuhan untuk mengelola bumi, yaitu sebagai khalifah dan sekaligus sebagai abd dihadapan Allah SWT.

Ilmu Dakwah: Academic Journal for Homiletic Studies, Vol. 10 No.2 | Juli-Des 2016109 
Atas dasar itulah, dapat diketahui bahwa Adat Ngalaksa yang hidup dan tumbuh di tengah masyarakat Rancakalong merupakan kreativitas yang dibangun atas nilai-nilai budaya dan semangat ajaran yang dibangun atas nilai-nilai Islami, Imani, dan Ihsani yang diharapkan dapat memberikan kesejahteraan dan kebahagiaan bagi mereka. Karena jiwa Adat Ngalaksa dilandasi oleh semangat rasa syukur atas karunia Allah SWT dalam bentuk keberhasilan pertanian atau panen padi yang mereka dapatkan. Dalam perspektif Islam, perilaku syukur ini merupakan bagian dari ajuran syari'at sebagaimana disampaikan dalam QS. Ibrahim [14] : 7. Dan (ingatlah juga), tatkeala Tubanmu memaklumkan; "Sesunggubnya jika kamu bersyukur, pasti Kami akan menambah (nikmat) kepadamu, dan jika kamu mengingkari (nikmat-Ku), Maka Sesunggubnya azab-Ku sangat pedih.

Pada aspek tertentu dapat dipandang sebagai perwujudan sikap arif dan bijaksana para pengembang Islam di wilayah Rancakalong dalam mensikapi persoalan dengan tidak mengabaikan budaya lokal yang berkembang di tengah masyarakat setempat.

Dalam bahasa ushul figh sebagai upaya mendahulukan pencegahan keburukan daripada mewujudkan kebaikan. Sebagaimana dalam ungkapan ushul al-fiqh yang berbunyi: Mencegah keburukan, harus lebih didabulukan daripada mewnjudkan kebaikan. Dalam rumusan ushul alfiqh yang lain disebutkan bahwa: "Mencegah bahaya, lebih utama daripada menarik datangnya kebaikan."

Perilaku individu dan sosial seperti yang terjadi pada masyarakat Rancakalong dipahami sebagai perilaku yang digerakan oleh kekuatan dari dalam yang didasarkan pada nilai-nilai ajaran agama yang menginternalisasi sebelumnya, sebagaimana dalam gambaran sejarahnya ketika masuk dan berkembang di tengah masyarakat Rancakalong pada masa awal, yaitu sekitar abad ke-16 M. Oleh karena itu, keyakinan keagamaan yang bersifat subjektif, kemudian diobjektifkan dalam berbagai macam ungkapan, dan perilaku masyarakat. Dimana ungkapan dan perilaku tersebut dipengaruhi oleh struktur tertentu yang dapat dipahami oleh masyarakat setempat.

Dengan begitu, terdapat hubungan interdependensi yang terusmenerus antara agama dan masyarakat juga terdapat pengaruh timbal balik antar kedua faktor tersebut. Pengaruh timbal balik antara keyakinan agama dan masyarakat semakin memberikan gambaran bahwa di antara unsur-unsur kebudayaan dan keyakinan agama pada dasarnya tidak berdiri sendiri, tetapi berkaitan dengan dimensi lain di luar dirinya. Selain dibentuk oleh substansi ajarannya, dimensi ini juga dipengaruhi oleh

110 Ilmu Dakwah: Academic Journal for Homiletic Studies, Vol. 10 No.2 | Juli-Des 2016 
struktur sosial dengan suatu keyakinan yang dimanifestasikan oleh para pemeluknya sehingga dalam konteks tertentu, di satu sisi keyakinan agama dapat beradaptasi, dan pada sisi lain dapat berfungsi sebagai alat legitimasi dari proses perubahan yang terjadi di sekitar kebudayaan para pemeluknya.

Pemahaman dan keyakinan masyarakat Rancakalong masih dirasa kuat, terutama terhadap simbol-simbol yang terdapat pada Adat Ngalaksa. Karena senyatanya lambang-lambang itu mampu membangkitkan perasaan dan keterikatan lebih daripada sekedar formulasi verbal, terutama terhadap simbol atau lambang yang dipercayai sebagai lambang yang memiliki nilai sakral. Lambang-lambang yang terdapat pada Adat Ngalaksa, sepanjang sejarahnya, juga sampai dengan saat ini masih menjadi pendorong yang cukup kuat bagi timbulnya perasaan masyarakat Rancakalong. Kondisi ini, secara akademik diperkuat oleh Elizabeth K. Nottingham, yang menyatakan bahwa:

Salah satu cara untuk menghidupkan benda-benda dan makhlukmakhluk sakral yang gaib dalam pikiran dan jiwa para pemeluk (agama), simbolisme, meskipun kurang tepat dibandingkan dengan cara-cara ekspresi yang lebih ilmiah, tetap mempunyai potensi istimewa. Karena lambang-lambang itu mampu membangkitkan perasaan dan keterikatan lebih daripada sekedar formulasi verbal, dari benda-benda yang mereka percayai sebagai lambang tersebut. Lambang-lambang perasaan dan keterikatan lebih daripada sekedar formulasi verbal dari benda-benda yang mereka percayai sebagai lambang tersebut. Lambang-lambang tersebut sepanjang sejarah dan juga sampai sekarang merupakan pendorong-pendorong yang paling kuat bagi timbulnya perasaan manusia. Karena itu tidak sukar untuk dipahami bahwa dimilikinya lambang bersama merupakan cara yang sangat efektif untuk mempererat persatuan di antara para pemeluk (agama) di dunia ini. Ini tidak lain karena makna lambang-lambang tersebut menyimpang jauh dari definisi-definisi intelektual sehingga kemampuan lambang-lambang tersebut untuk mempersatukan lebih besar; sedangkan definisi-definisi intelektual menimbulkan perpecahan. Lambang-lambang bisa dimiliki bersama karena didasari perasaan yang tidak dirumuskan terlalu kuat (Nottingham, 2002: 14).

Dalam perspektif sejarahnya, unsur budaya Islam sangat jelas kelihatan. Masyarakat Rancakalong menurut sejarahnya baru mengenal

Ilmu Dakwah: Academic Journal for Homiletic Studies, Vol. 10 No.2 | Juli-Des 2016111 
cara-cara bertanam padi adalah padi waktu mereka ditaklukan oleh bala tentara Mataram pada abad 16, yaitu sekitar tahun 1620 M. Pada waktu itu Sumedang Larang sebagai kerajaan pewaris Pajajaran Sunda, jelas Islam Sunda merupakan pola tradisi yang telah membentuknya secara sinkretik yang rajanya Prabu Geusan Ulun telah takluk kepada Mataram Islam karena secara terus-menerus diserangnya. Setelah takluk, kemudian masyarakatnya banyak memeluk Islam dengan pola-pola ke Mataraman sehingga banyak adat dan tradisi mereka mengikuti pola-pola tuannya. Karena secara administratif, kerajaan tersebut menginduk kepada kerajaan Mataram Islam.

Berdasarkan hal itu jelaslah bahwa padi atau bisanya masyarakat Sumedang bercocok tanam padi adalah disebabkan karena pengaruh Mataram Islam. Kemudian, Islam yang dibawa oleh Mataram pada saat itu menurut Simuh (1988: 11), adalah Islam Kejawen yang dibawa oleh Sultan Agung. Pada masa itu Sultan Agung berusaha mendorong proses Islamisasi tradisi dan kebudayaan Jawa. Sedangkan ia memerintah dari tahun 1613 hingga tahun $1645 \mathrm{M}$.

Jadi, semakin jelas bahwa sejarah pengaruh budaya Islam terhadap Adat Ngalaksa di Rancakalong Sumedang, dipengaruhi oleh ajaran Islam yang disebarkan oleh Kerajaan Mataram yang beragama Islam pada saat Sultan Agung. Karena menurut hemat penulis, bahwa Islam masuk ke Sumedang dari Mataram tersebut terjadi sekitar tahun $1620 \mathrm{M}$, dan merupakan tahun kejayaannya Sultan Agung Mataram dalam gerakannya proses Islamisasi tradisi dan kebudayaan Jawa ke tanah pasundan. Sekalipun, Islam pada saat itu adalah Islam yang sudah mengalami sinkretis dengan tradisi Hindu yang lebih dulu telah berkembang di tanah Jawa. Hal tersebut sebagaimana dikatakan oleh Rachmat Subagja Subagja (1981: 127) bahwa ritus kaum petani banyak memuat istilah Hindu dan Islam yang sangat kuno.

Dengan demikian, meminjam pendapat Berger dan Luckmann bahwa pemahaman masyarakat Rancakalong atas Upacara Ngalaksa merupakan pemahaman realitas sosial, yaitu sebuah pengetahuan yang bersifat keseharian yang hidup dan berkembang di masyarakat seperti konsep, kesadaran umum, wacana publik, sebagai hasil dari konstruksi sosial. Dengan demikian realitas sosial dikonstruksi dalam dialektika melalui proses eksternalisasi, objektivikasi, dan internalisasi. Dengan kata lain, Berger dan Luckmann sebagaimana dijelaskan oleh Nugroho (dalam Bungin: 13), beranggapan bahwa konstruksi sosial tidak berlangsung

112 Ilmu Dakwah: Academic Journal for Homiletic Studies, Vol. 10 No.2 | Juli-Des 2016 
dalam ruang yang hampa (empty space), melainkan sarat dengan sejumlah kepentingan.

Pada kasus ini, yaitu pemahaman masyarakat Rancakalong terhadap adat Ngalaksa, mereka berupaya membayangkan bagaimana institusi tersebut eksis; kondisi ini akan menjadi kembali (come to be) seperti pada awal terbentuknya. Kondisi ini disebut sebagai pembaharuan atau reification dan institusi dikatakan "telah diperbaharui" (reified) (Kuswarno, :106).

Berdasarkan data di lapangan, diketahui bahwa masyarakat Rancakalong secara keseluruhan sebagai masyarakat penganut dan pengamal syari'at Islam. Tentu, existing keyakinan keagamaan yang terdapat pada masyarakat Rancakalong, dan unsur-unsur normatif yang terkandung pada keyakinan (agama) ini, karena agama tidak hidup dalam ruang hampa, maka dalam aktualisasinya nilai-nilai keagamaan ini merupakan bagian dari kebudayaan, baik terkait dengan (1) unsur-unsur yang menyangkut penilaian (valuational elements); (2) Unsur-unsur yang berhubungan dengan apa yang seharusnya (precriptive elements); dan (3) unsur-unsur yang menyangkut kepercayaan (cognitive elements) (Soekanto, : 198).

Dengan demikian, unsur-unsur pada hubungan sosial merupakan bagian dari kebudayan, apalagi bila berpegang pada pendapat Mac Iver yang menyatakan bahwa "kebudayaan adalah ekspresi jiwa yang terwujud dalam cara-cara hidup dan berpikir, pergaulan hidup, seni kesusastraan, agama, rekreasi dan hiburan" atau didasarkan pada pendapat Kingsley Davis yang menyatakan bahwa kebudayaan mencakup "segenap cara berpikir dan bertingkah laku, yang timbul karena interaksi yang bersifat komunikatif' (dalam Soekanto, : 341-343).

Oleh karena itu, bukan sesuatu yang mustahil jika pada tataran kehidupan sosio-kultural masyarakat Rancakalong dalam pengamalan dan perilaku budaya, lebih kental dengan nilai dan syariat ajaran Islam. Karena Islam yang telah membudaya dalam praktek kehidupan masyarakat Rancakalong, akan mempengaruhi cara berpikir dan bertingkah laku, sebagai akibat dari adanya interaksi yang bersifat komunikatif antara budaya dengan nilai ajaran Islam.

Dalam realitasnya, pengamalan Islam pada masyarakat Rancakalong telah mengalami akulturasi, semacam dialog antara Islam dengan kebudayaan lokal yang hidup dan berkembang pada masyarakat setempat yang memiliki, sekaligus berfungsi sebagai suatu mekanisme

Ilmu Dakwah: Academic Journal for Homiletic Studies, Vol. 10 No.2 | Juli-Des 2016113 
adaptif yang membuat manusia mampu menjaga kehidupan sosial sebagai komunitas yang teratur (Morris, 2007: 151).

Pengamalan nilai-nilai adat Ngalaksa sebagai bagian dari experiential involvement pada masyarakat Rancakalong, diperkirakan dipengaruhi oleh keyakinan dan pemahaman keagamaan, yang di dalamnya telah terjadi kompromi antara nilai dan simbol agama yang diyakininya sebagai agama yang sebarkan oleh Kerajaan Mataram, dengan kebudayaan lokal yang telah hidup dan tumbuh subur di tengah masyarakat pada waktu itu. Kondisi inilah yang disebut sebagai dialektika inhern dari fenomena masyarakat (Kahmad, 2011: 72), dan keadaan ini disebut oleh Peter L. Berger sebagai dialektika sosial (Berger, 1991: 4).

Pengamalan "budaya baru" sebagai perpaduan dan kompromi antara ajaran dan nilai budaya lokal, dalam bantuk adat Ngalaksa pada masyarakat Rancakalong, di satu sisi secara substansial merupakan implementasi ajaran Islam, sebagaimana dijelaskan dalam Al-Quran surat Hud (11) ayat 120, yang menjelaskan bahwa di dalam sejarah terdapat pelajaran (mau'idzath) dan peringatan (zikra) yang akan mengukuhkan hati manusia. Karena peristiwa sejarah yang pernah terjadi bukanlah merupakan peristiwa yang mati, melainkan merupakan peristiwa yang masih hidup di masa kini.

Bukti lainnya yang menunjukkan indikasi pengamalan nilai-nilai dan pesan moral yang disampaikan pada lagu jentreng tarawangsa yang sering dimainkan di acara puncak Adat Ngalaksa, adalah masih hidup dan suburnya hidup sederhana, tradisi saling berbagi di tengah masyarakat Rancakalong, yaitu dalam bentuk saling mengirim beras kepada orang yang akan hajatan, membangun rumah, acara selamatan. Karena di antara pesan moral pada adat Ngalaksa adalah mengajarkan nilai-nilai gotong royong, saling membantu dan meringankan beban orang lain.

Experiential involvement seseorang tergantung atas budayanya, dalam hal ini budaya Adat Ngalaksa juga berpengaruh terhadap pengamalan kehidupan sehari-hari masyarakat Rancakalong. Berkaitan dengan persoalan ini, Richard E. Porter dan Larry A. Samovar, menyatakan bahwa :

Budaya berkenaan dengan cara manusia hidup. Manusia belajar berpikir, merasa, mempercayaai dan mengusaakan apa yang patut menurut budayanya. Bahasa, persahabatan, kebiasaan makan, prkatik kkomunikasi, tindakan-tindakan sosial, kegiatan-kegiatan ekonomi dan politik, dna teknologi, semua itu berdasarkan pola-pola budaya. Ada

114 Ilmu Dakwah: Academic Journal for Homiletic Studies, Vol. 10 No.2 | Juli-Des 2016 
orang-orang yang berbicara Tagalog, memakan ular, menghindari minuman keras terbuat dari anggur, menguburkan orang-orang yang mati, berbicara melalui telepon, atau meluncurkan roket ke bulan, ini semua karena mereka telah dilahirkan atau sekurang-kurangnya dibesarkan dalam suatu budaya yang mengandung unsur-unsur tersebut. Apa yang orang-orang lakukan, bagaimaan mereka bertindak, bagaimaan mereka hidup dan berkomunikasi, merupakan respons-resopns terhdap dan fungsi-fungsi dari budaya mereka (Mulyana dan Rakhmat, 2003: 18).

Berdasarkan data di lapangan diketahui, bahwa upacara ngalaksa sekalipun bagian dari adat yang hidup dan berkembang di tengah masyarakat Rancakalong, tetapi diyakini dan dipahami oleh para pelakunya merupakan bagian dari pelaksanaan syari'at. Selain karena secara substantif merupakan implementasi dari rasa syukur atas karunia yang telah diberikan oleh Alloh SWT, yang telah dikembangkan sejak lama oleh para karubun (leluhur) yang beragama Islam, juga dilaksanakan oleh para penganut Islam yang terdapat di Wilayah Rancakalong.

Selanjutnya eskpresi ini mewujud dalam bentuk simbolik "Adat Ngalaksa", dan keadaan ini semakin menguatkan pendapat Mircea Eliade yang berpandangan bahwa seluruh fenomena keagamaan itu mempunyai karakter simbolik, dan bahkan dengan mengikuti Cassirer serta lainnya, dia mendefinisikan manusia sebagai Homo Symbolicus. Dan setiap perilaku religius memiliki muatan makna yang dalam tahap akhirnya bersifat "simbolik", karena ia mengacu pada nilai atau sesuatu yang supranatural (dalam Morris, 2007: 220). Bahkan Eliade manyatakan hal yang melebihi fakta bahwa pengalaman religius dibentuk melalui simbolisme (dalam Morris, 2007: 223).

Pada sisi lain, dampak Adat Ngalaksa dapat menjadi integrator di antara masyarakat yang berbeda kampung (rurukan), karena di antara mereka diikat oleh kesamaan keyakinan dan kesamaan adat istiadat, sehingga adat Ngalaksa yang dipandang oleh sebagian masyarakat Rancakalong sebagai bagian dari proses implementasi nilainilai agama, pada gilirannya merupakan bagian yang tidak terpisahkan dari sistem keyakinan atau agama yang hidup dan berkembang di tengah masyarakat Rancakalong, dan pada gilirannya ikut mempengaruhi tata pikir dan tata laku warga masyarakat Rancakalong. Karena nilai yang dimiliki oleh sekelompok masyarakat. 


\section{PENUTUP}

Dakwah berbudaya atau dakwah kultural merupakan salah satu strategi dakwah yang efektif dalam menyampaikan pesan-pesan keagamaan. Seperti yang terlihat di masyarakat Rancakalong Sumedang. Dengan memakai Adat Ngalaksa, pesan keagamaan begitu kuat melekat di masyarakat Sumedang, tetapi nilai-nilai luhur budaya tetap eksis.

\section{DAFTAR PUSTAKA}

Berger, Peter L. (1991). Langit Suci: Agama sebagai Realitas Sosial, Jakarta: LP3ES.

Bungin, Burhan. (2001). Imaji Media Massa, Yogyakarta: Jendela.

Cuzzort dan King. (1987). Kekuasaan, Birokrasi, Harta dan Agama di Mata Max Weber dan Emile Durkheim, Penyunting Mulyadi Guntur Wasesa, Yogyakarta: Hanindita.

Geertz, Clifford. (1989). Santri, Priyayi dan Abangan, Jakarta: Pustaka Jaya.

Hajriyanto Y. Tohari, "Agama dan Realitas Budaya," dalam PESAN No. 26/Th.I/VII/1999.

Ishomudin. (2002). Pengantar Sosiologi Agama. Bogor: Ghalia Indonesia.

Kahmad, Dadang. (2011). Sosiologi Agama. Bandung: Remaja Rosdakarya.

Koentjaraningrat, (1995). Manusia dan Kebudayaan di Indonesia, Jakarta: Penerbit Djambatan.

Kuswarno, Engkus. (2009). Metodologi Penelitian Komunikasi Fenomenologi: Konsepsi, Pedoman, dan Contoh Penelitian Fenomena Pengemis Kota Bandung, Bandung: Widya Padjadjaran.

Mahasin, Aswab (ed.). (1996). Rub Islam dalam Budaya Bangsa: Aneka Budaya Nusantara, Jakarta: Yayasan Festival Istiqlal.

Morris, Brian. (2007). Antropologi Agama: Kritik Teori-teori Agama Kontemporer, Cetakan Kedua, Yogyakarta: AK Group.

Mulyana, Deddy dan Rakhmat, Jalaluddin. (2003). Komunikasi Antarbudaya: Panduan Berkomunikasi dengan Orang-orang Berbeda Budaya, cet. ke-7, Bandung: Remaja Rosdakarya.

Nina Herlina L. (Ketua Tim Penulis), (2008). Sejarah Sumedang Dari Masa Ke Masa, Sumedang: Dinas Pariwisata dan Kebudayaan Pemerintah Kabupaten Sumedang.

116 Ilmu Dakwah: Academic Journal for Homiletic Studies, Vol. 10 No.2 | Juli-Des 2016 
Nottingham, Elizabeth K. (2002). Agama dan Masyarakat: Suatu Pengantar Sosiologi Agama, Jakarta: PT. RajaGrafindo Persada.

Pals, Daniel L. (2001). Seven Theories of Religion, Jakarta: Penerbit Qalam.

Robertson, Roland. (ed). (1993). Agama: Dalam Analisis dan Interpretasi Sosiologis,Jakarta: Raja Grafindo Persada.

Schraf, Betty R. (1995). Kajian Sosiologi Agama, Yogyakarta: PT. Tiara Wacana Yogya.

Soekanto, Soerjono. (2015). Sosiologi: Suatu Pengantar, Jakarta: Rajawali Press.

Subagja, Rachmat. (1981). Agama Asli Indonesia, Jakarta: Cipta Loka Caraka.

Tajiri, Hajir. (2015). Etika dan Estetika Dakwah: Perspektif Teologis, Filosofis, dan Praktis. Bandung: Simbiosa Rekatama Media.

Ilmu Dakwah: Academic Journal for Homiletic Studies, Vol. 10 No.2 | Juli-Des 2016117 